\title{
Hydrogeological Investigation and Groundwater Potential Assessment in Haromaya Watershed, Eastern Ethiopia
}

\author{
Nata Tadesse $^{1 *}$, Bheemalingeswara ${ }^{1}, \mathrm{~K}$ and Abdulaziz $^{2}, \mathrm{M}$ \\ ${ }^{1}$ Department of Earth Science, College of Natural and Computational Sciences, Mekelle \\ University, Mekelle, Ethiopia (*tafesse24603@yahoo.com) \\ ${ }^{2}$ Harari National Regional State Agricultural and Rural Development Bureau, Harar, Ethiopia
}

\begin{abstract}
The paper assesses groundwater quality and productivity in Haromaya watershed, eastern Ethiopia. Continuous pumping test data, collected from seven boreholes was used to determine productivity of the aquifers. 14 water samples were tested for water quality. The aquifers on the basis of permeability, potential and extent of aquifers, are categorized into i) extended and shallow aquifers with intergranular porosity and permeability, and with moderate to high potential (alluvial and lacustrine sediments); ii) limited and shallow aquifers with fracture and/or karstic porosity and permeability, and with moderate potential (sandstone and limestone); and iii) limited and shallow aquifers with intergranular and fracture porosity and permeability, and with low potential (granite).

On the basis of chemical data, the water is fresh except in lacustrine and swampy areas. $\mathrm{HCO}_{3}{ }^{-}$, $\mathrm{Ca}^{2+}, \mathrm{Na}^{+}$and $\mathrm{Mg}^{2+}$ are the dominating ions in water from granite, sandstone and alluvium; and $\mathrm{Cl}$ and $\mathrm{SO}_{4}$ dominate in water from lacustrine sediments apart from $\mathrm{HCO}_{3}{ }^{-}, \mathrm{Ca}^{2+}, \mathrm{Na}^{+}$and $\mathrm{Mg}^{2+}$. Areas suitable for groundwater development in the area are discussed.
\end{abstract}

Keywords: Aquifer, Ethiopia, Groundwater potential, Haromaya, Hydrogeochemistry.

\section{INTRODUCTION}

The study area, Haromaya watershed in eastern Ethiopia, is currently serving as a source of groundwater supply for the three major towns: Harar, Alemaya, Awaday and Haromaya University main campus, besides the rural areas where the farmers are also extracting groundwater for different purposes. Sixteen functional boreholes and more than 160 hand-dug wells are found drilled in the watershed. In principle, the development of groundwater in an area should be preceded by an investigation of the groundwater resources. Continued development thereafter will increase the importance of the groundwater as contributor for the socio-economic development of the area. However, this is not the case in the study area. Besides in the area there is no regulation for the abstraction of water from these wells. Also there is no predetermined

prioritisation between different water uses and water users. All these practices expose the groundwater resources of the area to mismanagement and risk. 


\subsection{Description of the Study Area}

The study area, Haromaya watershed, is located in Oromiya Regional State, eastern part of Ethiopia, about $505 \mathrm{~km}$ east of Addis Ababa. Geographically, the study area is bounded between latitudes $42^{\circ} 05^{\prime} 16^{\prime \prime} \mathrm{N}$ and $43^{\circ} 55^{\prime} 12^{\prime \prime} \mathrm{N}$; and longitudes $9^{\circ} 21^{\prime} 40^{\prime \prime} \mathrm{E}$ and $9^{\circ} 27^{\prime} 13^{\prime \prime} \mathrm{E}$ with areal extent of about 50.3 sq. km (Fig. 1). The area is located in the Harerghe plateau in the southeastern highlands and lowlands physiographic unit of the country. The Harerghe highlands lying in the eastern part of the country are generally known for their rugged topography, mountainous landscapes which govern the variations in regional geomorphology, soil sequences, ecological zones, quantity and quality of plant and animal life (Tamire H., 1981). Steep to very steep slopes, hilly and mountainous area, which covers $18 \%$ of the total area of the watershed, characterize the eastern and northeastern parts of the watershed. Flat to gentle slopes, which cover $82 \%$ of the total area of the watershed and has a slope ranging $0-15 \%$, characterize the remaining parts of the watershed. This physiographic unit includes a swampy area that lies in the southwestern part of the watershed. The slope of the watershed rises slowly in all directions away from the swampy area.

The slope, landform and the configuration of the hills and peaks surrounding the study area have created a drainage network, which takes the surface flow towards the swampy area. The major streams are: Lega-Hidha, Lega-Ambo, Lega-Burqa and Lega-Bati and all the flows are intermittent. These streams are supplied by gullies, ephemeral streams, road channels and sometimes directly from overland flows of adjacent farmlands. The drainage pattern of the area is sparse dendritic type. The monthly air temperature of the watershed range from $3.8^{\circ} \mathrm{C}$ at December to $25.2^{\circ} \mathrm{C}$ in March, and the mean annual is $16.7^{\circ} \mathrm{C}$ (Nata et al., 2006). The highest value of the minimum temperature is $13.6^{\circ} \mathrm{C}$ and the lowest value of the minimum temperature is $3.8^{\circ} \mathrm{C}$, whereas the highest and lowest values of maximum mean temperatures are $25.2^{\circ} \mathrm{C}$ and $22.5^{\circ} \mathrm{C}$, respectively. The minimum mean and maximum mean temperatures are $9.6^{\circ} \mathrm{C}$ and $23.8^{\circ} \mathrm{C}$, respectively.

Present research work was proposed to conduct hydrogeological investigation and assess groundwater potential of the Haromaya watershed with following objectives.

- Identification of the major water bearing formations;

- Characterization of different aquifers;

- Determination of aquifer productivity: transmissivity and hydraulic conductivity; and 
- Determination of chemical-type and quality of water.

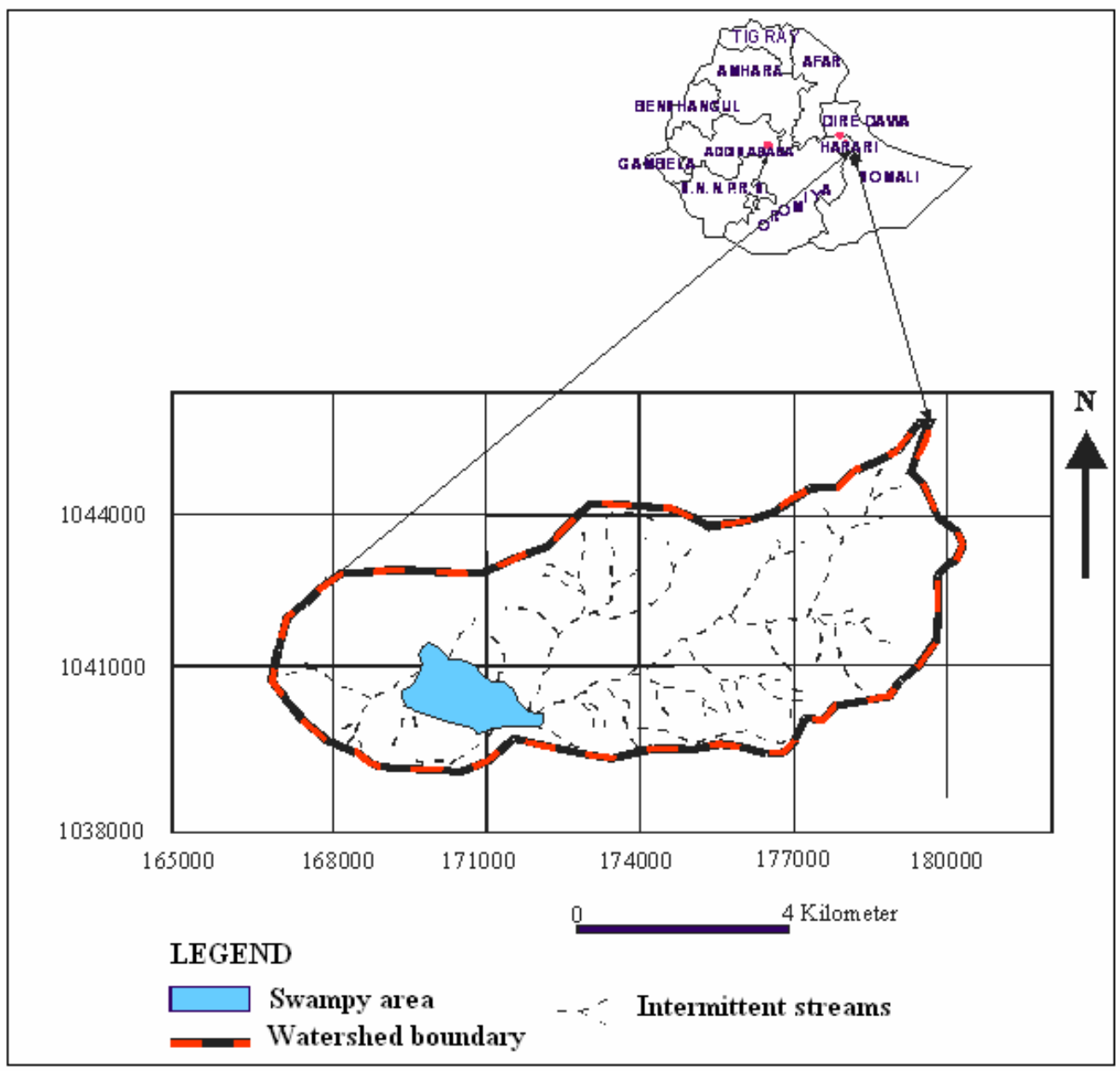

Figure 1. Location map of the Haromaya watershed.

\section{METHODOLOGY}

The methods used in this study include literature review, field investigation, laboratory analysis and data analysis using different software. Aerial photographs and topographic maps at a scale of 1:50,000 (Karsa and Harar: with reference numbers 0941 D2 and 0942 C1, respectively) were studied carefully. The aerial photographs were used to identify the geological structures and trace them on to the topographic sheet of 1:50,000 scale. The topographic sheet was used as base map in the field to mark the lithologies, their contacts and trends and to develop detailed geological and hydrogeological maps of the area.

Primary geological and hydrogeolgical data were collected in the field after having the secondary data. Hydrogeological field investigation was concentrated more on differentiating the rock units 
of groundwater significance (such as the degree of fracturing of the rock units, the extent of weathering, the type and degree of cementation, the thickness of the formations, the grain size, shape and sorting, and the clay proportion) and in collecting hydrogeological information, i.e., locating of water points, collection of water samples, and measurement of discharge of wells.

For determining the productivity of the aquifers within the study area continuous pumping test data from seven boreholes drilled in unconsolidated aquifer were used. In the watershed, due to the unavailability of the piezometer and recovery data, the analyses have been performed only for constant rate pumping test by using the pumping borehole data. The drawdown data of all boreholes have been analyzed using Neuman method (Neuman, 1975; cited in Krešić, 1997): drawdown versus time. Analyses of all data have been carried out using AquiferTest software. The program contains analytical solutions for pumping and slug tests for confined, unconfined, and leaky confined aquifers. The classification of the aquifer productivity was carried according to Sen (1995) based on transmissivity values.

For hydrogeochemical investigation, 14 water samples (4 springs, 7 hand dug wells, and 3 boreholes) were collected for laboratory analyses. In-situ measurements of electrical conductivity (EC), temperature, $\mathrm{pH}$, and total dissolved solids (TDS) were made. The water samples were collected into properly cleaned and labeled one liter plastic bottles. The samples were again tested for EC, $\mathrm{pH}$, temperature and TDS in the laboratory to cross check the data. All the water samples were analyzed for major cations $\left(\mathrm{Ca}^{+2}, \mathrm{Mg}^{+2}, \mathrm{Na}^{+}, \mathrm{K}^{+}\right.$, total iron, $\mathrm{Mn}^{+2}, \mathrm{NH}_{4}^{+}$, and anions $\left(\mathrm{HCO}_{3}^{-}, \mathrm{Cl}^{-}, \mathrm{SO}_{4}^{-2}, \mathrm{CO}_{3}^{-2}, \mathrm{~F}^{-}, \mathrm{NO}_{2}^{-}, \mathrm{NO}_{3}^{-}, \mathrm{PO}_{4}^{-3}\right)$ in the Water Works Design and Supervision Enterprise laboratory service, Addis Ababa. Interpretation of all water chemistry data have been carried out using AquaChem software. AquaChem is a fully-integrated software package developed specifically for graphical and numerical analyses and interpretation of aqueous geochemical data sets. Piper diagram was used for representing and comparing water quality analyses in the watershed.

\section{GEOLOGY}

The geology of the watershed is constituted by the rocks ranging in age from Precambrian to Recent. Stratigraphically, from bottom to top, they are granite (Precambrian), sandstone and limestone (Mesozoic sedimentary rocks) and recent sediments (Quaternary) (Fig. 2). Detailed description of these units is given below. 


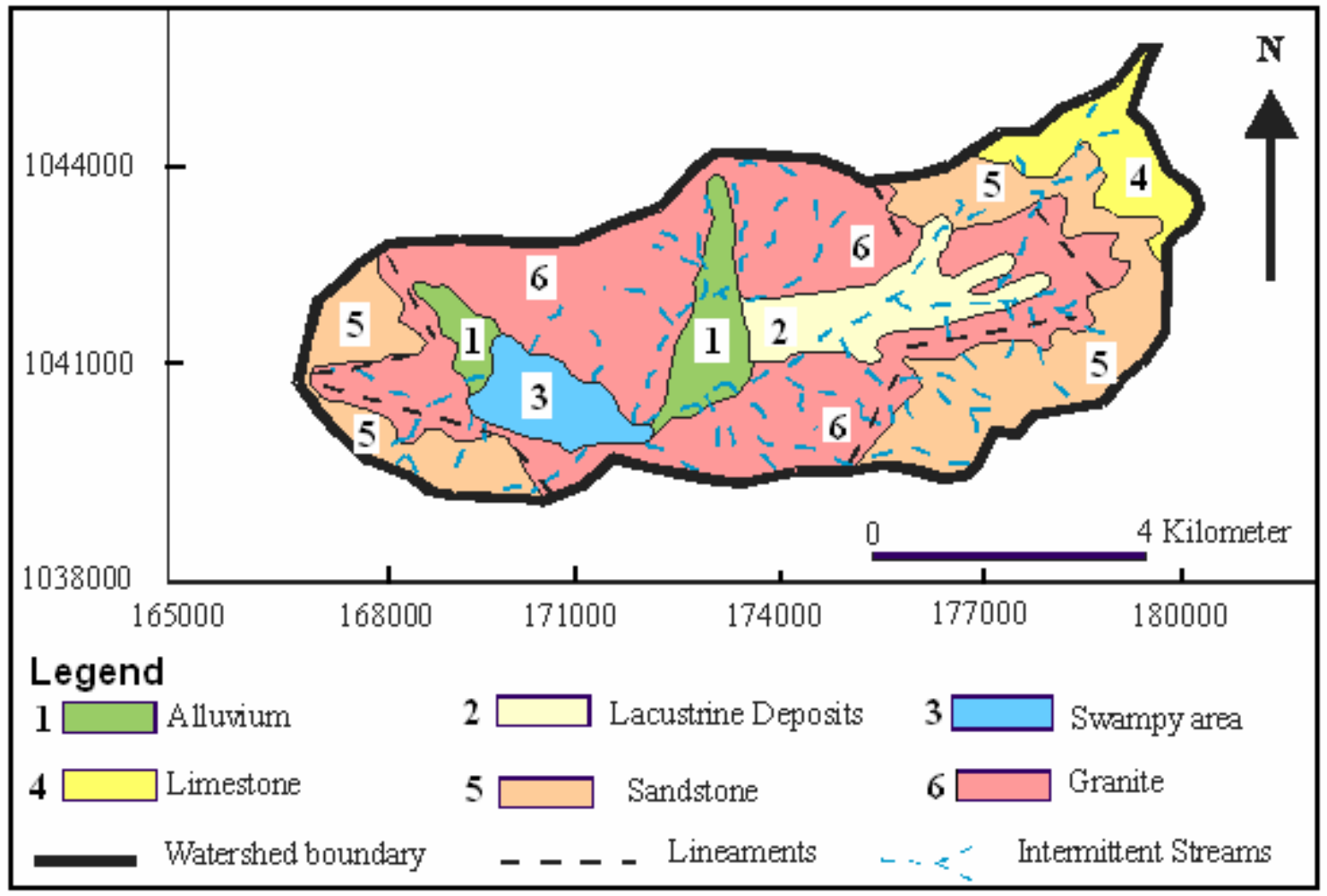

Figure 2. Geologic map of the Haromaya watershed.

\subsection{Granite}

This rock forms part of the Precambrian stratigraphy of Ethiopian geology. It is an intrusive pluton present within the basement gneissic rocks. It is mainly exposed in the north, northeastern, eastern, southeastern, southern and central parts of the watershed. This unit covers about $46.3 \%$ of the total area of watershed. The granite (batholith) rock is massive and shows light pink color. It is characterized by well developed medium grained quartz and orthoclase crystals. It is cut across and intersected by a number of quartz veins having thickness of about 3 to 10 centimeters and with predominantly north-south orientation. The length of the veins ranges from few $\mathrm{cm}$ to $1.5 \mathrm{~m}$. Granite, with the exception of the northern ridges, is highly weathered in other parts of the watershed and shows light gray color. Maximum thickness of the weathered granite is about $25 \mathrm{~m}$ which is found in a river cut exposure in western parts of the watershed.

\subsection{Sandstone}

The Mesozoic sedimentary successions of the watershed consist of two formations, the sandstone and limestone. Both together cover about $19.4 \%$ of the total area of the watershed. Sandstone unit is outcropping in the eastern, northeastern, northwestern, western, and southwestern parts of 
the watershed and overlie the basement granite, and occupies $14.3 \%$ of the mapped area. It shows yellowish to pink color and predominantly consists of fine to medium grained quartz. The rock shows well sorted, rounded grains, cross bedding and red color on the surface due to weathering. It is non-calcareous except at the top near the contact with the overlying limestone, where thin beds of limestone have developed. In the southwestern part, reddish brown massive mudstone intercalations are found in sandstone varying in thickness from $20 \mathrm{~cm}$ to $1 \mathrm{~m}$. Average thickness of the sandstone unit ranges from 20 to $200 \mathrm{~m}$, and shows well developed vertical joints (Nata et al., 2006). Generally the sandstone is highly weathered and fractured, and found forming hills and ridges in the area. In all parts where it is exposed, it is found covered with shallow soil. The age of the sandstone is Triassic (Garland, 1972).

\subsection{Limestone}

The outcrops of this unit are present in the northeastern part of the watershed. It overlies the sandstone unit and cover about $5.1 \%$ of the mapped area having a maximum thickness of about $180 \mathrm{~m}$ (Nata et al., 2006). The limestone is fossiliferous and micritic having very fine grained calcite crystals. It shows intercalations of thin beds of light brownish color marl varying in thickness from 3 to $5 \mathrm{~m}$. It shows gray and light yellowish to black colors due to weathering. At places the unit is highly weathered and shows well developed karst topography. The rock occupies high elevations in the topography and forms steep cliffs in the area. This unit is regionally correlated with the Upper Hamanlei Formation of the Ogaden basin and the Antalo Formation of northern Ethiopia, which is considered to be Upper Jurassic (Mohr, 1963).

\subsection{Alluvial Deposits}

The alluvial deposits are mainly found in the central part of the watershed as thin strips along the margins of the major rivers and their tributaries. These sediments constitute about $16.7 \%$ of the total area and show E-W alignment. They stretch from the eastern and northeastern parts from the bottom of the mountain to the swampy area. The relative abundance and stratigraphic relation of the sediments, however, are generally not uniform throughout the area. Towards the mountain front, which is in the northeastern and eastern parts of the watershed, where steep topographic slopes exist and the gradient of the rivers is high, the alluvial sediments, in general, are dominated by sub-angular to sub-rounded coarse grained fragments with variable content of coarse grained sand. In the central parts of the watershed, where the gradient of the rivers 
decreases down slope, the dominant alluvial deposit is medium to fine grained sand with variable content of silt and clay.

\subsection{Lacustrine Deposits}

The lake sediments are found occupying the dried Haromaya lake and also in the current swampy area of the watershed. It covers about $17.7 \%$ of the total area. Compositionally the deposits are comprised of clay and silt in different proportions. The sediments are characterized by well developed hexagonal cracks having an opening space ranging from 1 to $5 \mathrm{~cm}$.

\section{RESULTS AND DISCUSSIONS}

\subsection{Hydrogeology}

\subsubsection{Aquifer Types}

Different rocks and unconsolidated sediments in the study area which behave as aquifers have been classified on the basis of permeability which they exhibit and the extent of the aquifer. They are:

1. Extended and shallow aquifers with intergranular porosity and permeability (unconsolidated sediments: alluvial and lacustrine sediments);

2. Limited and shallow aquifers with fracture and/or karstic porosity and permeability (sandstone and limestone); and

3. Limited and shallow aquifers with intergranular and fractured porosity and permeability (Granite).

\subsubsection{Aquifer Characteristics}

Groundwater occurrence and its reservoirs are mainly controlled by the type of geology, degree of geological weathering or geological structures, and geomorphology of the area. In this section the hydrogeological characteristics of the different rocks and unconsolidated sediments of the watershed have been discussed with particular reference to their water storage and transmission capacities.

\subsubsection{Unconsolidated Sediments}

The recent sediments, which cover about $34.4 \%$ of the total mapped area in the form of lacustrine and alluvium serve as one of the major storage volumes for water flowing from the nearby highlands. Alluvial deposits in the central part of the watershed and as thin strips along the margins of the major rivers and their tributaries are the most common shallow aquifers which 
can be tapped by large diameter hand dug wells. Their permeability and productivity vary from place to place depending on their grain size, sorting and thickness. Lacustrine sediments on the other hand are dominantly fine grained with clay, and their thickness range from 3 to $18 \mathrm{~m}$, most being between 10 to $18 \mathrm{~m}$ (Fig. 3). Being rich in clay, the sediments have a very low permeability and productivity and serve as confining or semi-confining layers. The poor drainage characteristics of these sediments lead to water logging.

\begin{tabular}{|c|c|c|c|c|c|c|c|c|}
\hline \multicolumn{9}{|c|}{ Wm HEW 3} \\
\hline $\begin{array}{l}\text { Depth h } \\
{[\mathrm{m}]}\end{array}$ & Hole & Annulus & Casing & Screen & & & Lithology & $\begin{array}{l}\text { Eev. } \\
\text { [m] }\end{array}$ \\
\hline $\begin{array}{l}5 \\
5 \\
10 \\
15 \\
15 \\
20 . \\
25 \\
30 \\
35\end{array}$ & & & & & 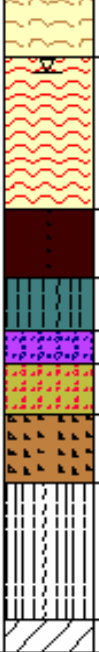 & $\begin{array}{l}4 \\
\frac{13}{17} \\
\frac{17}{20} \\
\frac{25}{29} \\
\frac{29}{3}\end{array}$ & $\begin{array}{l}\text { Elack Clay Highly Reworked } \\
\text { CLAY } \\
\text { Brown Clay } \\
\text { Reworked Sediment with fine sand } \\
\text { SAND With Gravel } \\
\text { SAND With Reworked Sediment } \\
\text { Highly Weathered gniess } \\
\text { Weathered Granite } \\
\text { Granite }\end{array}$ & 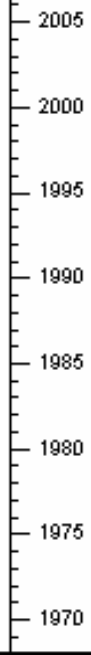 \\
\hline
\end{tabular}

Figure 3. Borehole log of the Haromaya watershed (after Abdulaziz and Nata, 2006 ).

\subsubsection{Sandstone}

In the watershed there is no borehole that was drilled and found in this unit. However, five hand dug wells are found drilled on it. The assessment of permeability and productivity of the sandstone was carried out based on field observation and limited lithological logs due to lack of pumping test data from boreholes in the watershed. Accordingly, the sandstone has moderate permeability and productivity. Its moderate permeability and productivity is resulting from the limited shale intercalation, bedding planes and the deep vertical jointing. Infiltration and recharge occur mainly through these joints and bedding planes. Its lack of high degree of permeability and productivity is due to the varying medium to fine grain size and degree of 
cementation. Generally, in the sandstone, intergranular permeabilities are low but secondary porosities and permeabilities due to fracturing are significant.

In the watershed, in most places sandstone forms hills and ridges. These landforms act as runoff zones. Even though limited infiltration can take place along fractures and joints, these landforms make the exploitation of groundwater resource of the formation quite limited because the groundwater availability in these types of landforms, in general, is very poor. However, a large number of high discharge springs characteristically emerge at the contact of the sandstone with the underlying basement rock.

Outside the watershed in the nearby area, the permeability and productivity of the sandstone were evaluated based on pumping test data of boreholes. Accordingly, the sandstone has a moderate permeability and productivity.

\subsubsection{Limestone}

In the watershed, the limestone has appreciable secondary porosity and permeability as a result of fractures, solution structures and openings along bedding planes. However, the degree of permeability and productivity of this formation is highly controlled by the landforms that it constitutes. The rock forms steep mountains and cliffs. These landforms act as runoff zones. Even though limited infiltration can take place along fractures and joints, these landforms make the exploitability of groundwater resource of the formation quite limited because the groundwater availability in these types of landforms in general is very poor. However, a few number of high discharge springs characteristically emerge at the contact of the limestone with the underlying sandstone. In the watershed there is no hand dug wells and boreholes that were drilled and found in this unit. Due to this, the assessment of the productivity of this unit as a whole was carried out based on field observation. Accordingly, this unit as a whole may be taken as an aquifer of poor productivity. This degree of productivity is associated mainly with the topography that it constitutes and to a lesser degree to the nature of the intercalated thin beds of marl.

\subsubsection{Granite}

The granite occurs as crosscutting intrusive bodies in the north, northeastern, eastern, southeastern, southern and central parts of the watershed, and is found covering $46.3 \%$ of the total area of watershed, having a maximum thickness of more than $100 \mathrm{~m}$ in the southeastern parts. The granite forms round shaped bodies and is affected by strong exfoliation due to the 
weathering processes. However, the weathering processes affected only the shallow upper parts of the rock. Following are the important features of granite which enhances its usefulness to the water supply:

- Occurrence of weathering zone;

- Occurrence of tectonic fractures;

- Contact with the surrounding metamorphic rocks; and

- Wide differences in composition, structure and texture and corresponding variability of the hydraulic parameters of the same rock.

In the watershed there is no borehole that was drilled and found in this unit. However, more than ten hand dug wells are found in it. The weathered layers and fractures are the main sources of groundwater supply in granitic rock of the watershed. As a result, the extent of weathering and fracture characteristics decide its hydraulic conductivity and other properties. In all the hand dug wells the main aquifer is found to be weathered and fractured granite. The depth of the hand dug wells range from 3.7 to $25.0 \mathrm{~m}$. The static water level ranges from 3 to $19 \mathrm{~m}$. The discharge of the hand dug wells ranges from 0.7 to $3 \mathrm{l} / \mathrm{s}$. Most of the hand dug wells are dried within 15 minutes when they were discharged with dewatering pump of $5 \mathrm{l} / \mathrm{s}$ discharge, indicating the low productivity nature of the rock. Assessment of the productivity of the weathered layers and fractured zones was carried out based on field observation and limited lithological logs due to lack of pumping test data from boreholes in the watershed. Accordingly, the weathered layers and fractured zones as a whole are estimated to have low permeability and productivity. This degree of permeability and productivity is due to the presence of medium to coarse grain sized particles and absence of secondary minerals in the weathered layers and limited infiltration that can take place along the fractures and joints. Their lack of moderate and high degree of productivity is mainly due to the limited thickness of fractured zones and weathered layers, the presence of fine grained materials both in the weathered layers and the overlying alluvium and the landforms which they form.

\subsection{Aquifer Productivity}

\subsubsection{Hydraulic Characteristics of Unconsolidated Sediment Aquifers}

All the boreholes ( 20 boreholes) and 158 of hand dug wells are found drilled in the sediments. Out of the twenty boreholes, four are abandoned and the rest are functional. The depths of the boreholes range from 13 to $66 \mathrm{~m}$ and the yields vary from 2 to $15 \mathrm{l} / \mathrm{s}$. The depths of static water 
level also vary from 2.2 to $14.0 \mathrm{~m}$. Among the boreholes and hand dug wells in the sediments of the watershed, only the performance of 16 boreholes have been checked by pumping test. However, pumping test data are available only for the seven boreholes of Hare Town Water Supply and Sewerage Authority. Pumping test and recovery test data were not obtained for the other nine boreholes and for all the 158 hand dug wells, and quantitative estimates of the performance of these boreholes and hand dug wells have not been determined. The following is the result of the analyses of the pumping test data obtained from the seven boreholes.

The Harer Emergency Well 1 borehole was drilled at elevation of $2018 \mathrm{~m}$ above seal level with a total depth of $47 \mathrm{~m}$. The static water level is $2.2 \mathrm{~m}$. The pumping test was conducted for 72 hours at a constant rate of $10.30 \mathrm{l} / \mathrm{s}$. After a continuous 72 hours pumping, a volume of $2669.76 \mathrm{~m}^{3}$ water was pumped out and a drawdown of $10.3 \mathrm{~m}$ was measured. According to the Neuman drawdown versus time method (Fig. 4), a transmissivity of $5.23 \times 10^{-4} \mathrm{~m}^{2} / \mathrm{s}$ and a hydraulic conductivity of $2.17 \times 10^{-5} \mathrm{~m} / \mathrm{s}$ have been computed.

The Harer Emergency Well 2 borehole was drilled at elevation of $2023 \mathrm{~m}$ above sea level with a total depth of $65 \mathrm{~m}$. The static water level is $13.9 \mathrm{~m}$. The pumping test was conducted for 24 hours at a constant rate of $4.46 \mathrm{l} / \mathrm{s}$. After a continuous 24 hours pumping, a volume of $285.344 \mathrm{~m}^{3}$ water was pumped out and a drawdown of $4 \mathrm{~m}$ was measured. In this borehole the recovery was fast. According to Harer Town Water Supply and Sewerage Authority (2003) cited in Abdulaziz and Nata, 2006) report, the borehole recovered $92 \%$ of the total drawdown within 5 minutes. The computed transmissivity and hydraulic conductivity values, by the Neuman drawdown versus time method (Fig. 5), are $1.4 \times 10^{-3} \mathrm{~m}^{2} / \mathrm{s}$ and $5.2 \times 10^{-5} \mathrm{~m} / \mathrm{s}$, respectively.

The Harer Emergency Well 3 borehole was drilled at elevation of $2015 \mathrm{~m}$ above sea level with a total depth of $39 \mathrm{~m}$. The static water level is $3.78 \mathrm{~m}$. The pumping test was conducted for 10 hours at a constant rate of $10 \mathrm{l} / \mathrm{s}$. After a continuous 10 hours pumping, a volume of $360 \mathrm{~m}^{3}$ water was pumped out and a drawdown of $10.63 \mathrm{~m}$ was measured. According to the Neuman drawdown versus time method (Fig. 6), a transmissivity of $5.2 \times 10^{-4} \mathrm{~m}^{2} / \mathrm{s}$ and a hydraulic conductivity of $2.88 \times 10^{-5} \mathrm{~m} / \mathrm{s}$ have been computed.

The Harer Emergency Well 4 borehole was drilled at elevation of $2013 \mathrm{~m}$ above sea level with a total depth of $52.3 \mathrm{~m}$. The static water level is $3.95 \mathrm{~m}$. The pumping test was conducted for 21 hours at a constant rate of $18 \mathrm{l} / \mathrm{s}$. After a continuous 21 hours pumping, a volume of $1360.8 \mathrm{~m}^{3}$ water was pumped out and a drawdown of $9.3 \mathrm{~m}$ was measured. According to the Neuman drawdown 
versus time method (Fig. 7), a transmissivity of $5.62 \times 10^{-4} \mathrm{~m}^{2} / \mathrm{s}$ and a hydraulic conductivity of $3.11 \times 10^{-5} \mathrm{~m} / \mathrm{s}$ have been computed.

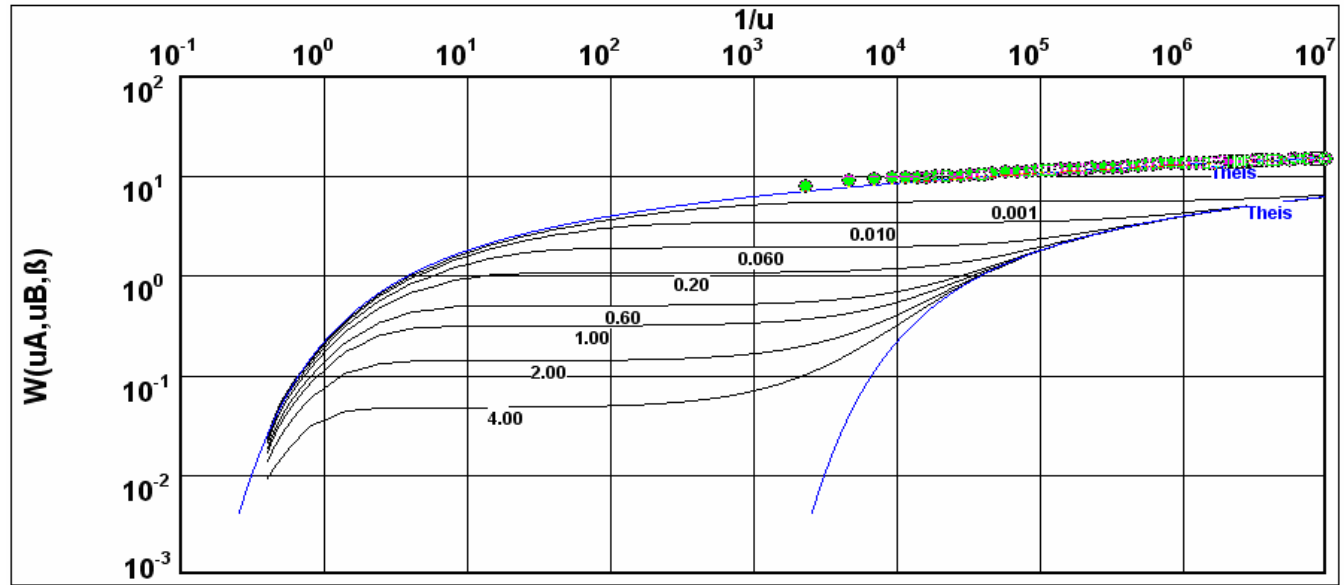

Figure 4. Neuman plot of drawdown versus time at the pumping borehole well 1.

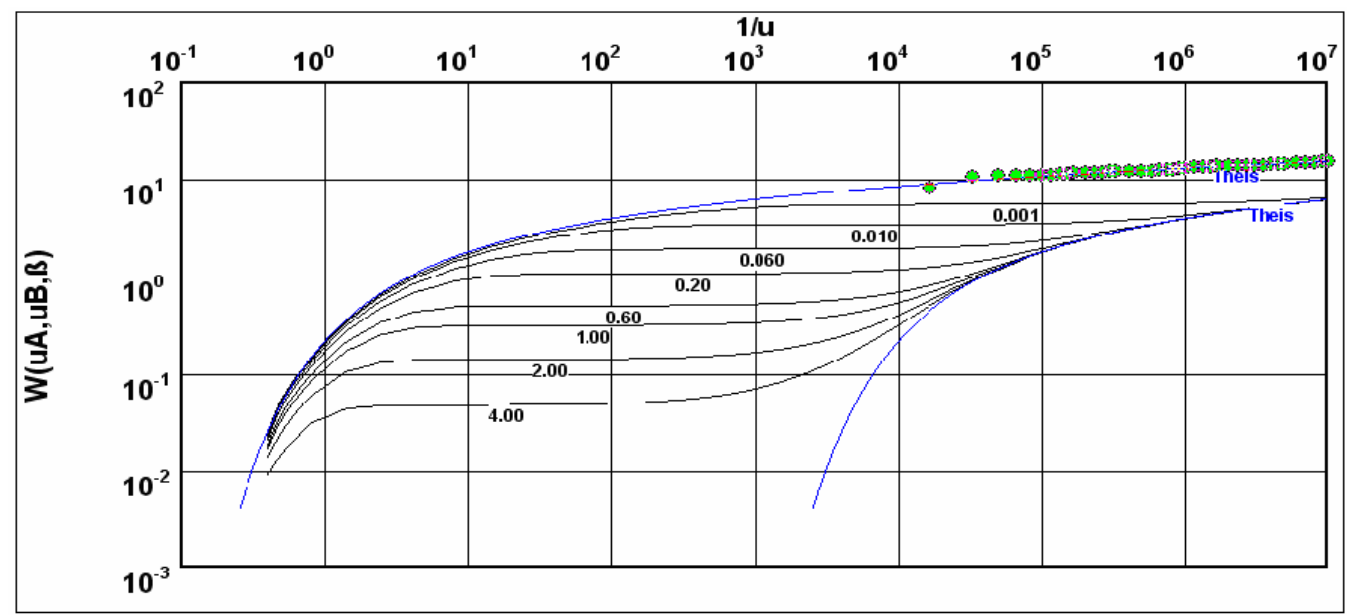

Figure 5. Neuman plot of drawdown versus time at the pumping borehole well 2.

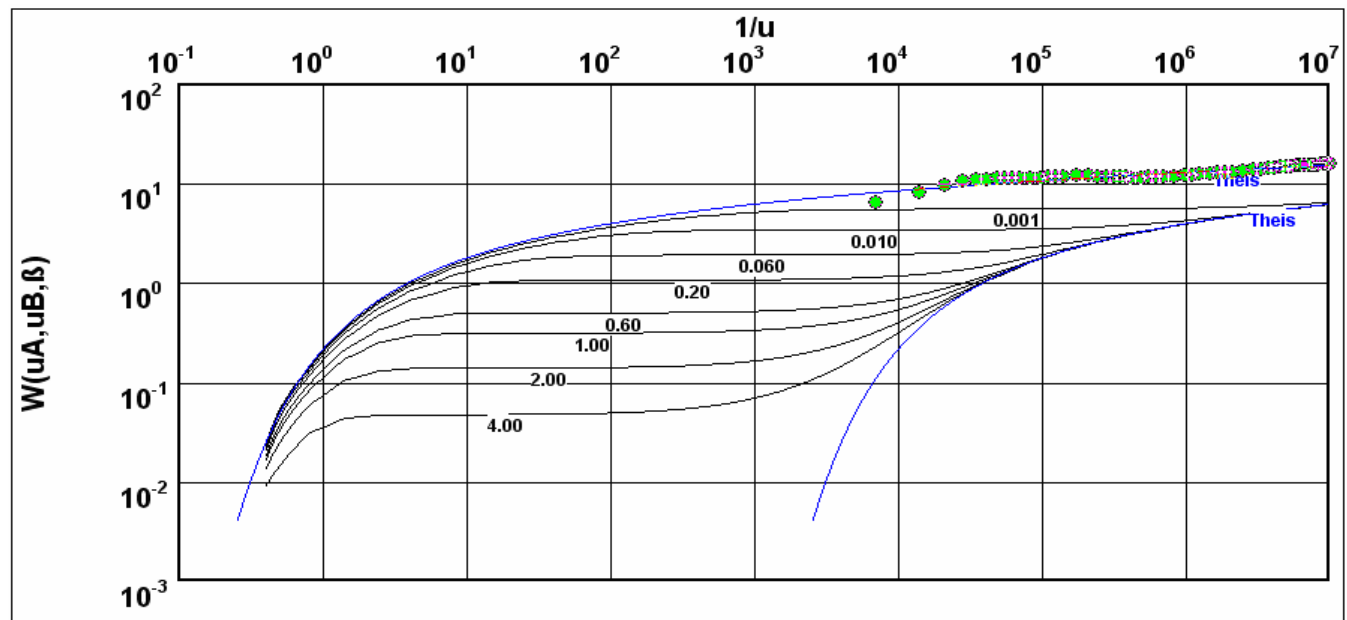

Figure 6. Neuman plot of drawdown versus time at the pumping borehole well 3. 


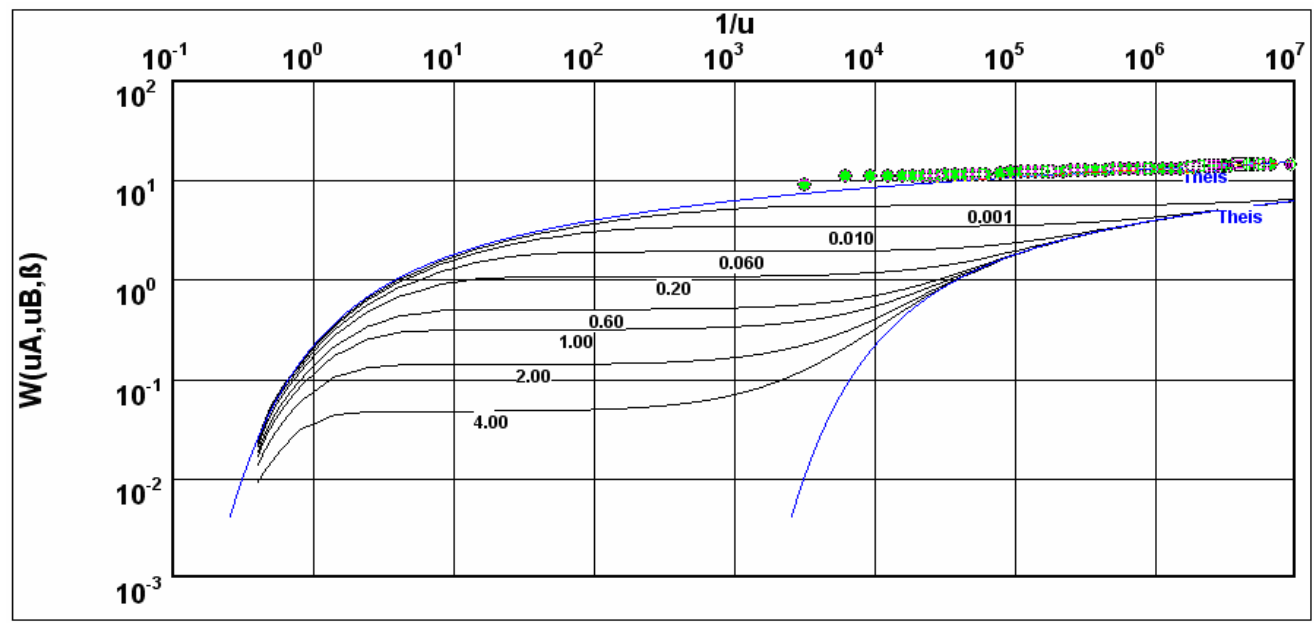

Figure 7. Neuman plot of drawdown versus time at the pumping borehole well 4.

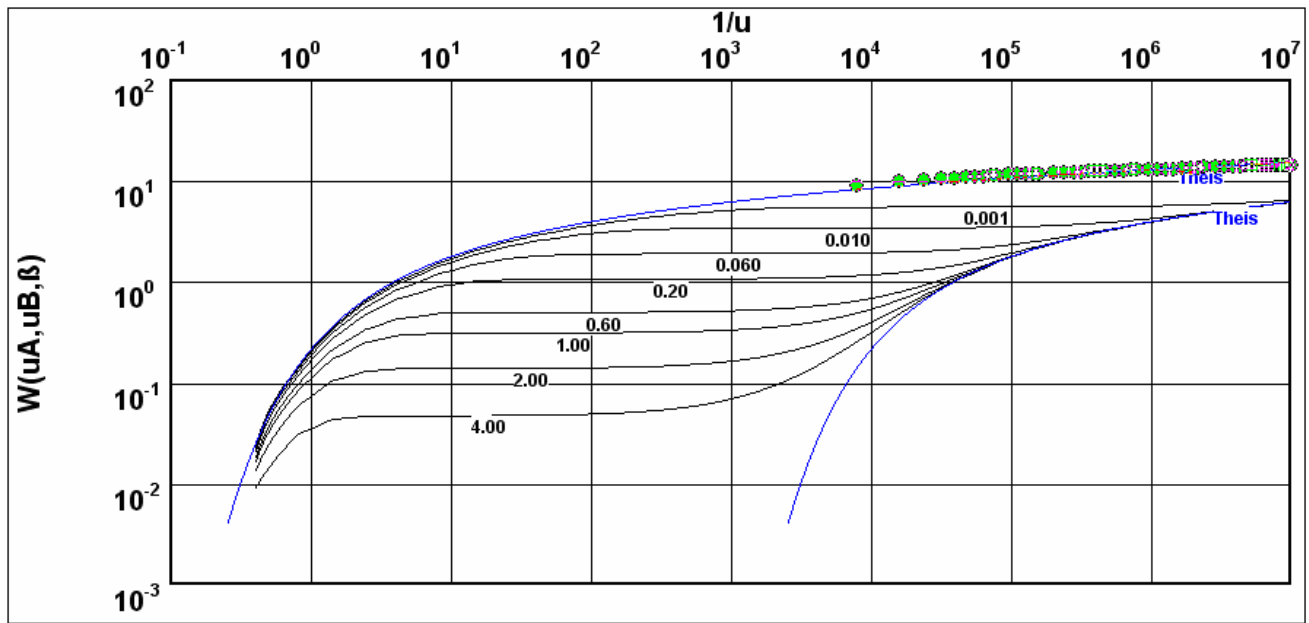

Figure 8. Neuman plot of drawdown versus time at the pumping borehole well 5.

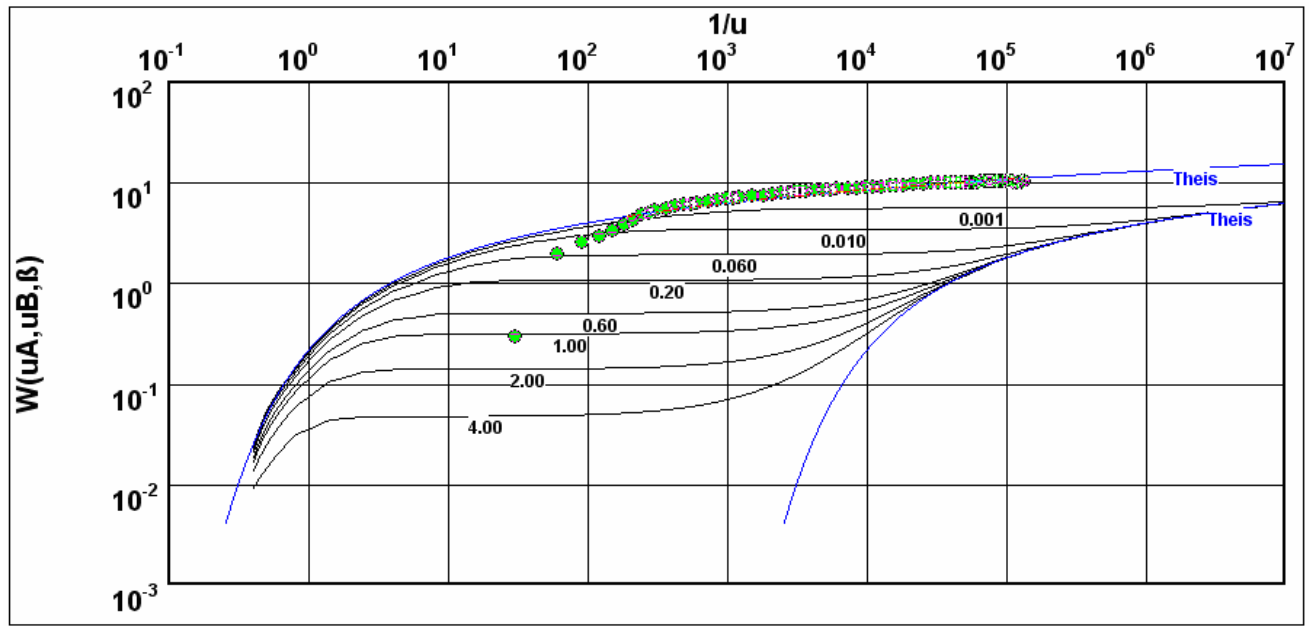

Figure 9. Neuman plot of drawdown versus time at the pumping borehole well 6 . 


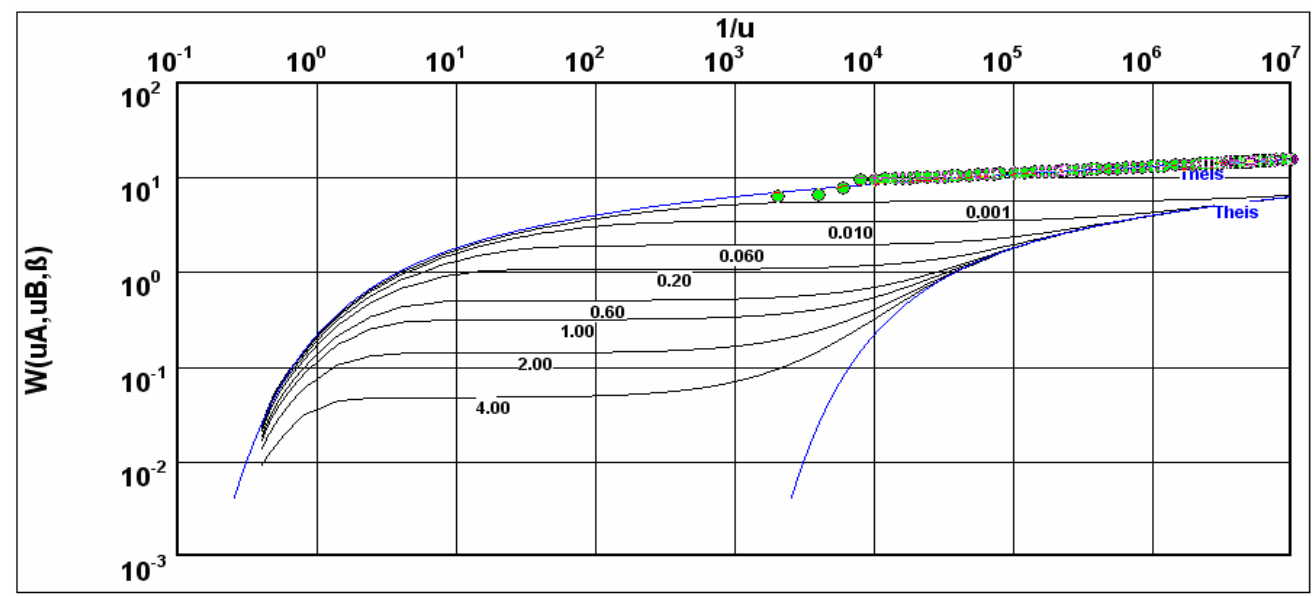

Figure 10. Neuman plot of drawdown versus time at the pumping borehole well 7.

The Harer Emergency Well 5 borehole was drilled at elevation of $2014 \mathrm{~m}$ above sea level with a total depth of $53 \mathrm{~m}$. The static water level is $2.89 \mathrm{~m}$. The constant rate pumping test was conducted for 48 hours at discharge rate of $18 \mathrm{l} / \mathrm{s}$. After a continuous 48 hours pumping, a volume of $3110.4 \mathrm{~m}^{3}$ water was pumped out and a drawdown of $8.91 \mathrm{~m}$ was measured. According to the Neuman drawdown versus time method (Fig. 8), a transmissivity of $5.78 \times 10^{-4} \mathrm{~m}^{2} / \mathrm{s}$ and a hydraulic conductivity of $2.4 \times 10^{-5} \mathrm{~m} / \mathrm{s}$ have been computed.

The Harer Emergency Well 6 borehole was drilled at elevation of $2011 \mathrm{~m}$ above seal level with a total depth of $44 \mathrm{~m}$. The static water level is $4.86 \mathrm{~m}$. The constant rate pumping test was conducted for 37 hours at a constant discharge of 16 1/s. After a continuous 37 hours pumping, a volume of $2131.2 \mathrm{~m}^{3}$ water was pumped out and a drawdown of $11.76 \mathrm{~m}$ was measured. According to the Neuman drawdown versus time method (Fig. 9), a transmissivity of $5.3 \times 10^{-4} \mathrm{~m}^{2} / \mathrm{s}$ and a hydraulic conductivity of $1.6 \times 10^{-5} \mathrm{~m} / \mathrm{s}$ have been computed.

The Harer Emergency Well 7 borehole was drilled at elevation of $2020 \mathrm{~m}$ above sea level with a total depth of $44 \mathrm{~m}$. The static water level is $5.65 \mathrm{~m}$. The constant rate pumping test was conducted for 41 hours at an average discharge rate of 22 1/s. After a continuous 41 hours pumping, a volume of $3247.2 \mathrm{~m}^{3}$ water was pumped out and a drawdown of $13.72 \mathrm{~m}$ was measured. According to the Neuman drawdown versus time method (Fig. 10), a transmissivity of $6.83 \times 10^{-}$ ${ }^{4} \mathrm{~m}^{2} / \mathrm{s}$ and a hydraulic conductivity of $2.62 \times 10^{-5} \mathrm{~m} / \mathrm{s}$ have been computed.

Generally, according to Sen (1995) classification, the aquifer potential of unconsolidated sediment aquifers ranges from moderate to high. 


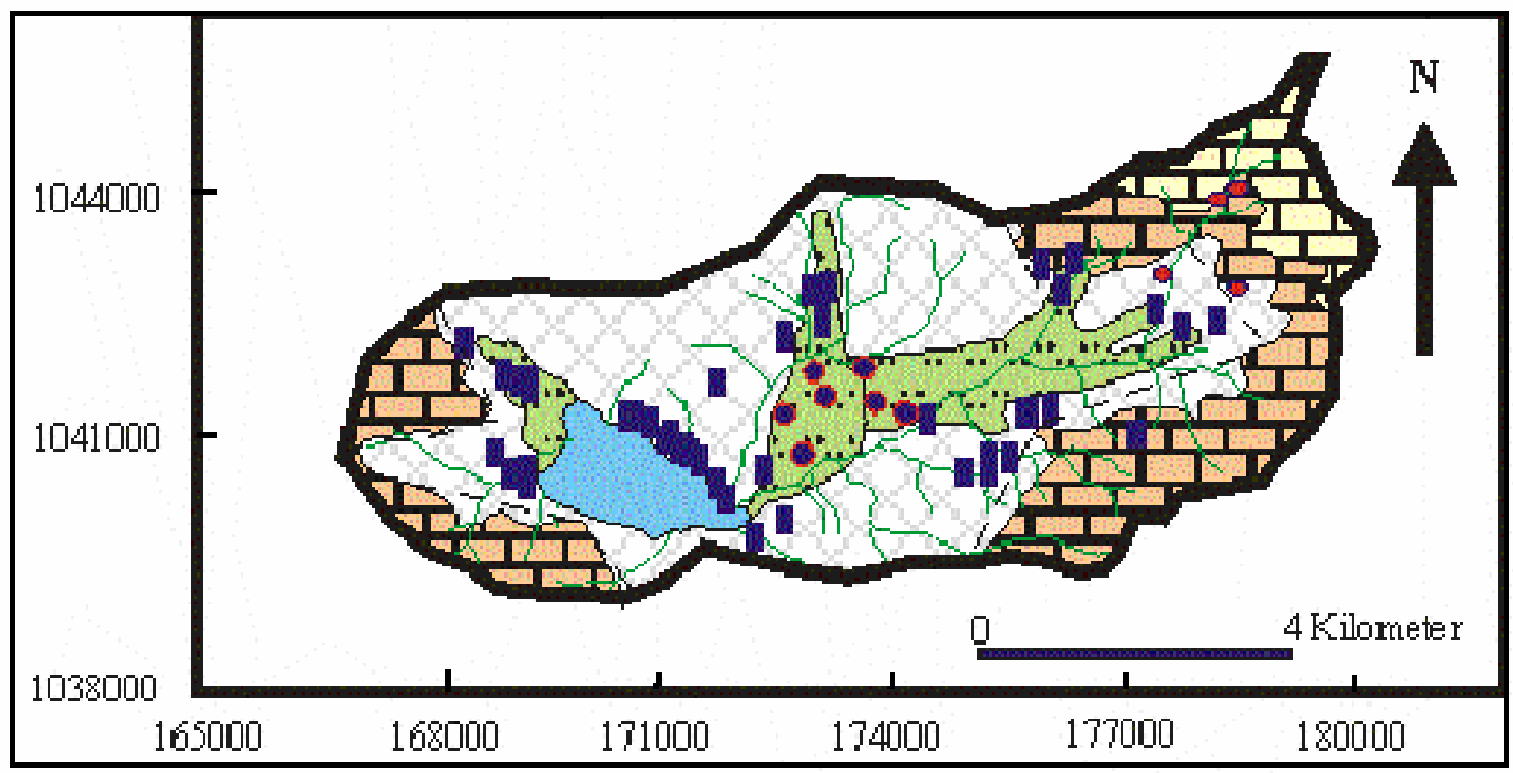

\begin{tabular}{|c|c|}
\hline \\
\hline $\begin{array}{l}\text { Legend } \\
\end{array}$ & $\begin{array}{l}\text { Extended and deep aquifers with intergranular porosity and } \\
\text { permeability (Unconsolidated sediments: Alluvial and Lacustrine Deposits) }\end{array}$ \\
\hline لبدبة & $\begin{array}{l}\text { Limited and shallow aquifers with fracture andior } \\
\text { karstic porosity and permeability (Sandstone and Limestone) }\end{array}$ \\
\hline$x \times x$ & $\begin{array}{l}\text { Limited and shallow aquifers with intergranular and fractured porosity } \\
\text { and perm eability (Granite) }\end{array}$ \\
\hline & Moderate to high potentiality Aquifer \\
\hline & Moderate potentiality Aquifer \\
\hline \multirow[t]{2}{*}{ 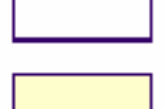 } & Low potentiality Aquifer \\
\hline & Weak or poor potentiality Aquifer \\
\hline \multirow[t]{5}{*}{---} & Lineaments \\
\hline & Boreholes \\
\hline & Hand Dug Wells \\
\hline & Spring \\
\hline & Swampy area \\
\hline \multirow[t]{2}{*}{$--<$} & Intermittent Streams \\
\hline & Watershed boundary \\
\hline
\end{tabular}

Figure 11. Hydrogeological map of the Haromaya watershed. 


\subsection{Hydrogeochemistry}

The results of the geochemical analyses are shown in the Tables 1 and 2 and in figures $12-15$, and are discussed below.

\subsubsection{Granite}

Five groundwater samples were analyzed from the granitic rock terrains of the watershed show slightly alkaline character. They are fresh (TDS less than $1000 \mathrm{mg} / \mathrm{l}$ ), neutral to slightly basic and very hard (Figs. 12A \& 13A). Alkalinity of the groundwater ranges from 193.8 to $354.9 \mathrm{mg} / \mathrm{l}$ $\mathrm{CaCO}_{3}$. Except in one, other samples show above $300 \mathrm{mg} / \mathrm{l} \mathrm{CaCO} 3$ alkalinity values (Fig. 13A). In terms of temperature the groundwater samples show variation from $19.7^{\circ} \mathrm{C}$ to $25.8^{\circ} \mathrm{C}$. Among the anions, $\mathrm{HCO}_{3}^{-}$is dominant over $\mathrm{Cl}^{-}$and $\mathrm{SO}_{4}{ }^{2-}$. The measured bicarbonate $\left(\mathrm{HCO}_{3}^{-}\right)$ concentrations range from $236.4 \mathrm{mg} / 1$ to $433.0 \mathrm{mg} / 1$ (Table.2; Fig. 14A). The anions $\mathrm{Cl}^{-}$and $\mathrm{SO}_{4}{ }^{2-}$ occur in only minor concentrations. The highest measured chloride concentration is $46.6 \mathrm{mg} / 1$ and the lowest is $12.4 \mathrm{mg} / \mathrm{l}$. The highest measured sulfate concentration is $49.4 \mathrm{mg} / \mathrm{l}$ and the lowest is $17.33 \mathrm{mg} / \mathrm{l}$. The bicarbonate concentration in granitic rock can be accounted for by the dissociation of water under the presence of carbon dioxide. The prevailing $\mathrm{pH}(6.8-8.5)$ (Table.1) is also one of the factors for the existence of the bicarbonate as major dissolved inorganic constituents in the groundwater. Over most of the normal $\mathrm{pH}$ range of groundwater (6 9), bicarbonate is the dominant carbonate species. The anions $\mathrm{Cl}^{-}$and $\mathrm{SO}_{4}{ }^{2-}$ are not significant constituents in silicate rocks. Since their occurrence is normally be attributed to atmospheric sources, to the decomposition of organic matter in soil, and to the trace impurities in rocks and minerals, there is no such condition exists in granite. Any possible increase of $\mathrm{SO}_{4}{ }^{2-}$ and $\mathrm{Cl}^{-}$is also restricted because of limited movement of groundwater.

Among cations, alkaline earths elements are relatively higher in concentration $\left(\mathrm{Ca}^{2+}\right.$ and $\left.\mathrm{Mg}^{2+}\right)$ compared to alkalis $\left(\mathrm{Na}^{+}\right.$and $\mathrm{K}^{+}$) (Table.2; Fig 14B). Without exception, $\mathrm{Ca}^{2+}$ is dominant over $\mathrm{Mg}^{2+}$. There is a dominance of $\mathrm{Na}^{+}$over $\mathrm{K}^{+}$, as sodium is more soluble than potassium, and the latter is generally more easily fixed on clay minerals in the rock matrix. Hence $\mathrm{K}^{+}$is the least abundant among cations. Chemical character of water varies from $\mathrm{Ca}-\mathrm{HCO}_{3}, \mathrm{Ca}-\mathrm{Na}-\mathrm{HCO}_{3}$, and $\mathrm{Ca}-\mathrm{Mg}-\mathrm{HCO}_{3}$ types (Fig.15). Though bicarbonate and alkaline earth elements are expected to be contributed from the rock but slightly higher amounts of $\mathrm{Na}$ compared to $\mathrm{K}$ is contributed from the overlying sediments. 


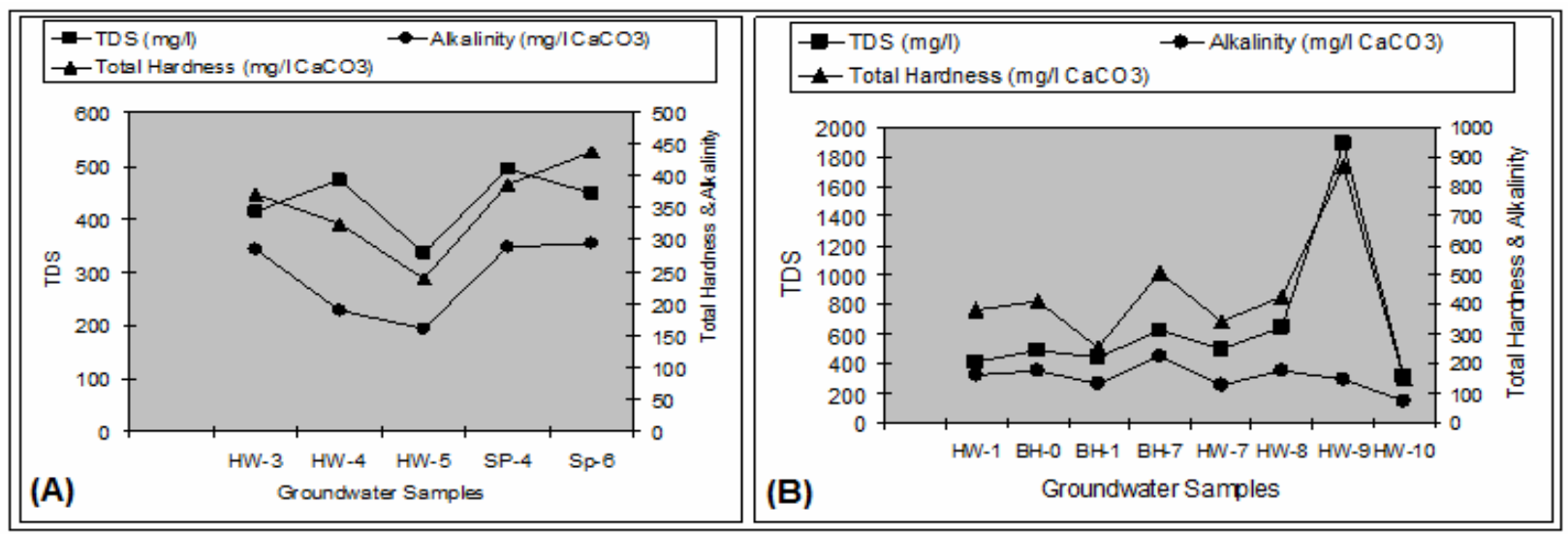

Figure 12. pH of the groundwater samples in (A) granite; (B) in sediment.
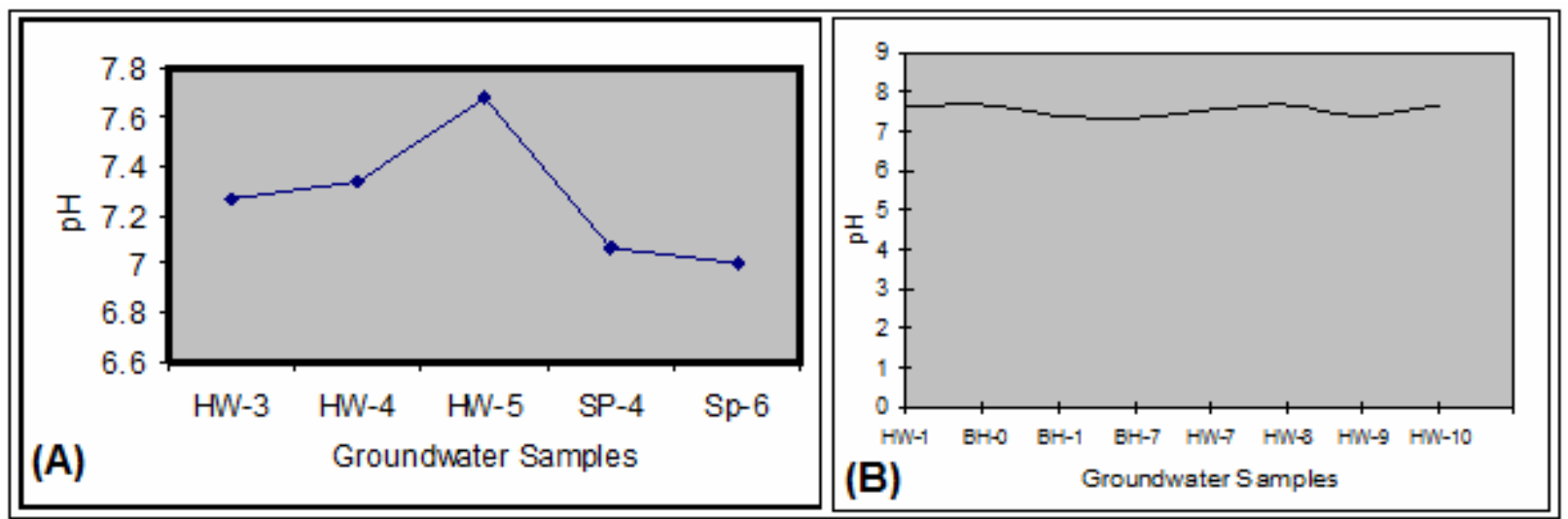

Figure 13. TDS, Alkalinity and Total hardness for groundwater (A) granite; (B) sediment.

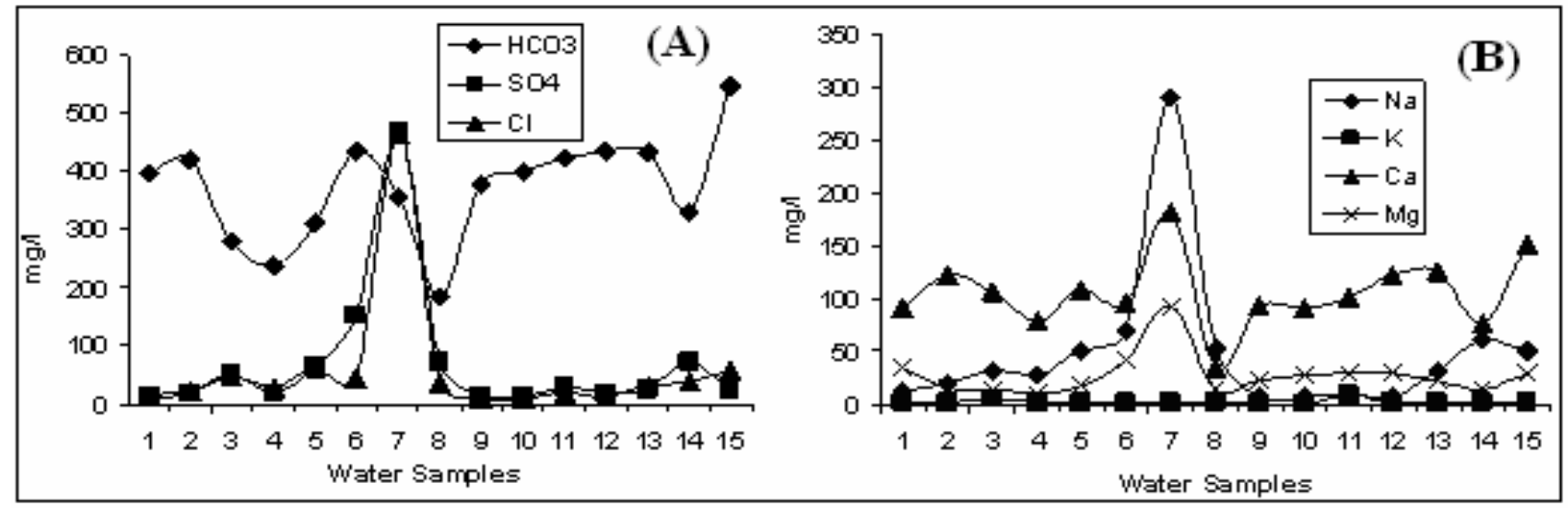

Figure 14. Variation in anion (A) and cation (B) concentrations in water (Note: water sample no. $1=\mathrm{HW}$ alluvial; $2-4=\mathrm{HW}$ granite; 5-8=HW lacustrine; 9-10=SP sandstone; 11-12=SP granite; $13-15=$ SP alluvial). 


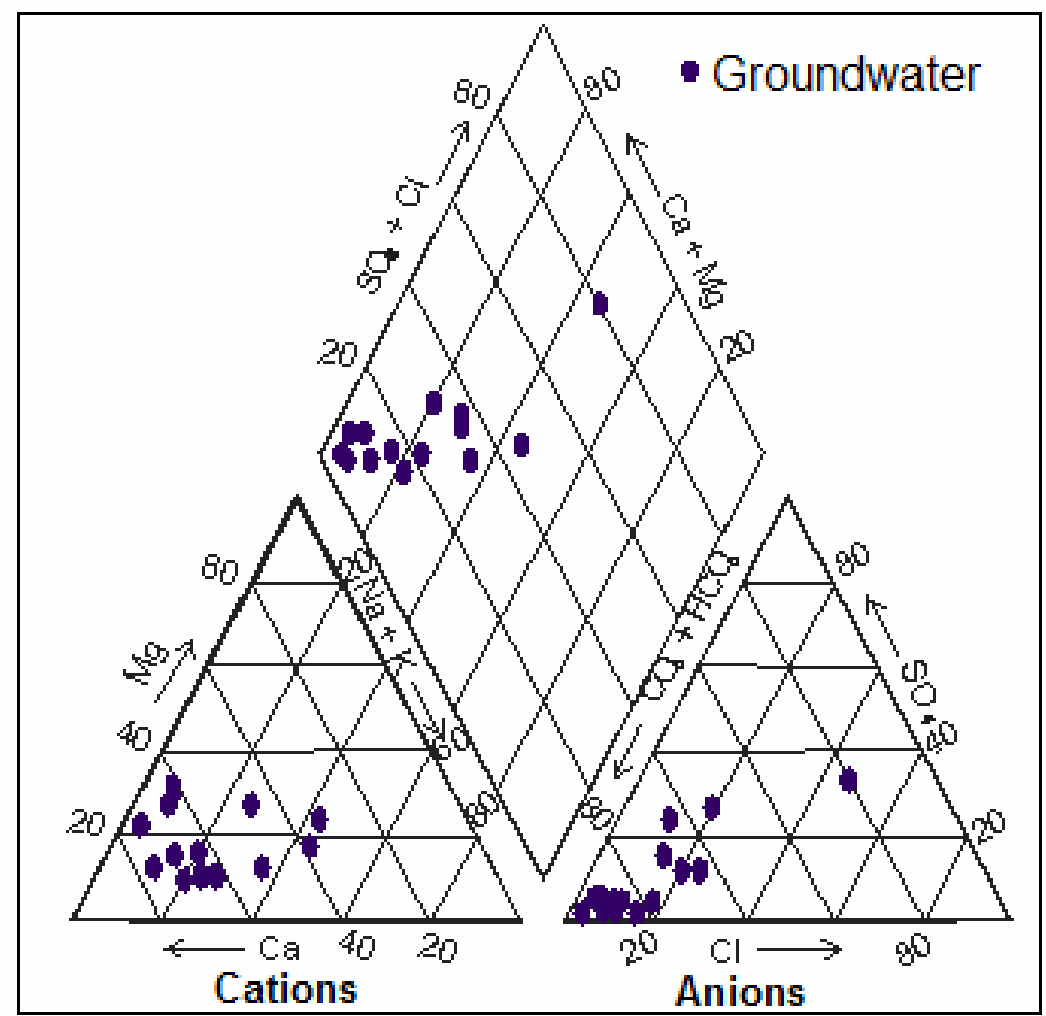

Figure 15. Piper diagram of hydrochemical data in the Haromaya watershed.

The fluoride content which ranges from trace to $0.5 \mathrm{mg} / \mathrm{l}$ (Table.2) is generally contributed from the fluoride-bearing minerals like apatite, fluorite and biotite in the rocks. Possible presence of minor amounts of biotite is expected to be the source for fluoride in the present case. Among secondary and minor constituents or trace elements total iron and manganese, both show very low concentrations below $0.5 \mathrm{mg} / \mathrm{l}$ (Table.2). These concentrations are low because of constraints imposed on the solubility of iron and manganese -bearing minerals or forming hydrous oxides of iron and manganese in the soil environment. Nitrite and ammonia concentrations in water samples are insignificant compared to the other nitrate nitrogen species. In all the analyzed samples the concentrations of nitrite is nil, but nitrate concentrations range from 7 to $21.5 \mathrm{mg} / \mathrm{l}$. The most abundant nutrient in water from all the samples is nitrogen in the form of nitrate. Unlike most other elements in groundwater, nitrate is not derived primarily from the minerals in rocks that make up the groundwater reservoir. Nitrate in groundwater generally originates from nitrate sources on the land surface, in the soil zone, or in shallow subsoil zones 
where nitrogen-rich wastes are buried. Natural nitrate concentrations in groundwater range from 0.1 to $10 \mathrm{mg} / 1$ (Davis and DeWiest, 1966). As shown in table 2, only in one hand dug well, the nitrate concentration is below $5 \mathrm{mg} / \mathrm{l}$. In the remaining four samples nitrate occurs at concentrations well above $10 \mathrm{mg} / \mathrm{l}$. Here the presence of nitrate is mostly attributed to the open pit latrines as there are no proper sewerage systems in the watershed. Ammonia concentrations are also very low ranging from 0.15 to $0.25 \mathrm{mg} / \mathrm{l}$ and generally contributed from anthropogenic or the overlying organic rich sediments.

Phosphate $\left(\mathrm{PO}_{4}{ }^{3-}\right)$ values are ranging from 0.041 to $0.123 \mathrm{mg} / \mathrm{l}$. In general phosphate concentration of groundwater in granitic rock terrains of the watershed is low, due to the presence of high concentration of calcium. The phosphate may be due to the presence of phosphorus-bearing minerals like hydroxylapatite $\left(\mathrm{Ca}_{5}(\mathrm{OH})\left(\mathrm{PO}_{4}\right)_{3}\right)$, strengite $\left(\mathrm{FePO}_{4} \cdot 2 \mathrm{H}_{2} \mathrm{O}\right)$ and varisite $\left(\mathrm{AlPO}_{4} \cdot 2 \mathrm{H}_{2} \mathrm{O}\right)$ in the rocks. The dominant control on phosphorus in the groundwater zone is the solubility of these slightly soluble phosphate minerals.

\subsubsection{Sandstone}

The chemistry of spring water in sandstone is slightly alkaline, fresh and very hard (Tables. $1 \& 2$ ). $\mathrm{Ca}^{2+}$ is dominant among cations and $\mathrm{HCO}_{3}{ }^{-}$among anions (Fig. $14 \mathrm{~A} \& \mathrm{~B}$ ). Alkalinity values ranges from 310.1 to $326.4 \mathrm{mg} / 1 \mathrm{CaCO}_{3}$ (Table. 1) and temperature from $18.5^{\circ} \mathrm{C}$ to $24.5^{\circ} \mathrm{C}$. In the sandstone aquifer the major ions in the groundwater calcium and bicarbonate assumed to be from calcite dissolution. Other cations magnesium, sodium and potassium are very low in water. Similarly, among anions, chloride and sulfate are also found in very small concentration. Chemical type of water is mainly $\mathrm{Ca}-\mathrm{Mg}-\mathrm{HCO}_{3}$ type (Fig. 15).

The measured fluoride concentrations are below $0.5 \mathrm{mg} / \mathrm{l}$. Natural concentrations of $\mathrm{F}^{-}$in groundwater mainly depends on the availability of $\mathrm{F}^{-}$in the rocks or minerals encountered by the water during its transport and on solubility constraints imposed on fluorite $\left(\mathrm{CaF}_{2}\right)$ or fluorapatite $\left(\mathrm{Ca}_{5} \mathrm{~F}\left(\mathrm{PO}_{4}\right)_{3}\right)$. The fact that nearly all groundwaters are undersaturated with respect to fluorite and fluorapatite suggests that the $\mathrm{F}^{-}$content of groundwater is generally limited due to nonavailability of $\mathrm{F}^{-}$in the rocks and sediments through which the groundwater moves rather than by the solubility these minerals (Freeze and Cherry, 1979).

Other anions like nitrite and ammonia show very low concentrations. Though, nitrite values are almost nil, the highest concentration recorded for ammonia is $0.188 \mathrm{mg} / \mathrm{l}$. On the other hand, the highest measured nitrate concentration is $19.5 \mathrm{mg} / \mathrm{l}$. This amount of concentration is mostly 
attributed to the open pit latrines as there are no proper sewerage systems in the watershed. The phosphate $\left(\mathrm{PO}_{4}{ }^{3-}\right)$ concentrations are also insignificant. As shown in the table 2, among trace elements, both total iron and manganese show very low concentrations and insignificant.

\subsubsection{Sediments}

Eight groundwater and spring water samples analysed from the sediments of the watershed indicate that they are slightly alkaline, fresh (except HW9), neutral $\mathrm{pH}$ and very hard (Table.1; Figs. 12B and 13B). In the case of the sample HW9, the water is brackish in character. Alkalinity values ranges from 148.9 to $446.8 \mathrm{mg} / 1 \mathrm{CaCO}_{3}$. Temperature values are ranging from $20.1^{\circ} \mathrm{C}$ to $24{ }^{\circ} \mathrm{C} . \mathrm{Ca}^{2+}$ is the dominant cation, followed by sodium $\left(\mathrm{Na}^{+}\right)$, magnesium $\left(\mathrm{Mg}^{2+}\right)$ and potassium $\left(\mathrm{K}^{+}\right)$ions in both the groundwater of the alluvial and lacustrine aquifers (Fig.14B). $\mathrm{HCO}_{3}{ }^{-}$is the dominant anion and $\mathrm{Cl}^{-}$the second most abundant anion followed by $\mathrm{SO}_{4}{ }^{2-}$ in the groundwater from alluvial aquifer (Fig.14A). Here, the anions $\mathrm{Cl}^{-}$and $\mathrm{SO}_{4}{ }^{2-}$ occur in only minor concentrations. However, in the groundwater from lacustrine aquifers $\mathrm{HCO}_{3}{ }^{-} \mathrm{Cl}^{-}$and $\mathrm{SO}_{4}{ }^{2-}$ ions show variation in concentration in all the samples. With the exception of sample HW9, in all other samples $\mathrm{HCO}_{3}{ }^{-}$is the dominant anion followed by $\mathrm{SO}_{4}{ }^{2-}$ as a second abundant anion in samples HW-8 and HW-10 and $\mathrm{Cl}^{-}$in sample HW-7. In the case of sample $\mathrm{HW}-9, \mathrm{Cl}^{-}$is the dominant anion and $\mathrm{SO}_{4}{ }^{2-}$ the second most abundant anion followed by $\mathrm{HCO}_{3}{ }^{-}$. Water samples from lacustrine sediments in general show high concentrations for the anions $\mathrm{Cl}^{-}$and $\mathrm{SO}_{4}{ }^{2-}$. This high concentration of $\mathrm{Cl}^{-}$and $\mathrm{SO}_{4}{ }^{2-}$ in the groundwater is mostly attributed to the dissolution of chloride and sulfate from lacustrine marl and evaporites, which can contribute salinity to the groundwater in this aquifer system. Fluoride concentrations are less than $1.2 \mathrm{mg} / \mathrm{l}$ in water from both the alluvial and lacustrine aquifers. The highest measured fluoride concentration is $1.1 \mathrm{mg} / \mathrm{l}$. Chemical types of groundwater from the alluvial aquifer are $\mathrm{Ca}-\mathrm{Mg}-\mathrm{HCO}_{3}$ and $\mathrm{Ca}-\mathrm{Na}-$ $\mathrm{HCO}_{3}$ types; and from the lacustrine sediment are $\mathrm{Ca}-\mathrm{Na}-\mathrm{HCO}_{3}-\mathrm{Cl}, \mathrm{Ca}-\mathrm{Mg}-\mathrm{Na}-\mathrm{HCO}_{3}-$ $\mathrm{SO}_{4}, \mathrm{Na}-\mathrm{Ca}-\mathrm{Mg}-\mathrm{Cl}-\mathrm{SO}_{4}$ and $\mathrm{Na}-\mathrm{Ca}-\mathrm{Mg}-\mathrm{HCO}_{3}-\mathrm{SO}_{4}$ types (Fig.15).

Nitrite and ammonia concentrations in groundwater from both alluvial and lacustrine aquifers are insignificant. Though groundwater is free from nitrite, it indicates presence of nitrate whose concentration is around $17.5 \mathrm{mg} / \mathrm{l}$. In the case of ammonia, the highest value recorded is 0.65 $\mathrm{mg} / \mathrm{l}$. Nitrate concentration is mostly attributed to the open pit latrines as there are no proper sewerage systems in the watershed. Other analysed parameters like phosphate $\left(\mathrm{PO}_{4}{ }^{3-}\right), \mathrm{Mn}$ and $\mathrm{Fe}$ (total) are insignificant in the groundwater from both the alluvial and lacustrine aquifers. 


\section{CONCLUSION}

- As part of hydrogeological investigation different types of aquifers are noted and demarcated.

- On the basis of the relationship between hydraulic properties and geology in the area, the aquifer rocks have been classified in to low, medium and high potential for groundwater.

- Among different aquifers, the one associated with unconsolidated sediments have moderate to high potential; followed by the sandstone having moderate potential and granite with low potential; and limestone characterized by weak and poor potential aquifers.

- Hydrogeochemical data indicate that the water in general is fresh except the water in lacustrine sediments and swampy areas as indicated by EC and TDS.

- Hydrogen ion concentrations though vary between 7 and 8; neutral values are observed in water from granite and sandstone; and slightly basic in lacustrine and swampy areas. Bicarbonate values that are closely related to $\mathrm{pH}$ though broadly follow the same trend show variations in the rocks and sediment.

- High concentrations of sulphate and chloride in lacustrine and swampy areas though are assumed to be due to increased residence time and they do not show any relation with hydrogen ion concentration.

- Among cations $\mathrm{Ca}^{2+}$ and among anions $\mathrm{HCO}_{3}{ }^{-}$are the dominating ions.

- Nitrate, ammonia and fluoride though low concentration, nitrate may increase with time from anthropogenic sources. Iron and manganese as expected are very low in concentration.

- Water from the rocks and sediment clearly indicate variation in their chemical character. $\mathrm{HCO}_{3}{ }^{-}, \mathrm{Ca}^{2+}, \mathrm{Na}^{+}$and $\mathrm{Mg}^{2+}$ are the dominating ions in water from granite, sandstone; and $\mathrm{Cl}$ and $\mathrm{SO}_{4}$ dominate in water from lacustrine sediments apart from $\mathrm{HCO}_{3}{ }^{-}, \mathrm{Ca}^{2+}, \mathrm{Na}^{+}$and $\mathrm{Mg}^{2+}$.

- Any future development of groundwater should be concentrated on the moderate to high degree potential aquifers.

- Further investigations are to be done to establish lateral extent and vertical thickness of the moderate to high degree potential aquifers; and to know the presence of additional multilayer aquifers, their respective thickness and productivity. 


\section{ACKNOWLEDGMENTS}

The Hare Town Water Supply and Sewerage Authority is duly acknowledged for funding this research project and also providing the necessary data. Thanks are also due to all those friends who helped during the field and laboratory work and for going through the manuscript many times and providing many constructive comments.

\section{REFERENCES}

Abdulaziz, M \& Nata, T. 2006. Optimum groundwater utilization and management in Lake Alemaya watershed, Eastern Ethiopia. Mekelle University, Mekelle, Ethiopia.

Davis, S.N \& DeWiest, R.J.M. 1966. Hydrogeology. John Wiley and Sons, New York, 463 pp.

Freeze, R.A \& Cherry, I.A. 1979. Groundwater, Prentice Hall, Inc., New Jersey.

Garland, C.R. 1972. Explanation of the Geological Map of Adigrat Sheet (ND 37-7), 1:250,000 Scale. Ethiopian Institutes of Geological Survey (E.I.G.S.), Addis Ababa.

Krešić, N. 1997. Quantitative solutions in hydrogeology and groundwater modeling, Lewis Publishers, Boca Raton.

Mohr, P.A. 1963. Geological Map of the Horn Africa, 1:2,000,000 Scale. Philip and Jacey, London.

Nata, T., Dubey, N., Mintesnot, K \& Shami, M. 2006. Water Balance of Haromaya basin, Oromiya, eastern Ethiopia. B.Sc thesis, Mekelle University, Mekelle, Ethiopia.

Şen, Z. 1995. Applied Hydrogeology, CRC Press, Boca Raton.

Tamire, H. 1981. Soil, water and forest conditions in Hararghe high lands, Alemaya. Unpublished report, Alemaya University, Alemaya, Ethiopia. 


\begin{tabular}{|c|c|c|c|c|c|c|c|c|c|c|}
\hline $\begin{array}{l}\text { Sample } \\
\text { ID }\end{array}$ & $\begin{array}{l}\text { Easting } \\
\text { (m) }\end{array}$ & $\begin{array}{l}\text { Northing } \\
\text { (m) }\end{array}$ & $\begin{array}{l}\text { Altitude } \\
\text { (m) }\end{array}$ & $p H$ & $\begin{array}{l}E C \\
(\mu S / \mathrm{cm})\end{array}$ & $\begin{array}{l}\text { TDS } \\
(\mathrm{mg} / \mathrm{l})\end{array}$ & $\begin{array}{l}\text { Alkalinity } \\
(\mathrm{mg} / \mathrm{l} \\
\left.\mathrm{CaCO}_{3}\right)\end{array}$ & $\begin{array}{l}\text { Total } \\
\text { Hardness } \\
\left.(\mathrm{mg} / \mathrm{l} \mathrm{CaCO})_{3}\right)\end{array}$ & Water Type & $\begin{array}{l}\text { Water-bearing } \\
\text { Formation }\end{array}$ \\
\hline HW-1 & 176750 & 1043171 & 2101 & 7.62 & 664 & 408 & 324.4 & 384.1 & $\mathrm{Ca}-\mathrm{Mg}-\mathrm{HCO}_{3}$ & Alluvial \\
\hline HW-3 & 175571 & 1041113 & 2051 & 7.27 & 693 & 414 & 342.7 & 371 & $\mathrm{Ca}-\mathrm{HCO}_{3}$ & Granite \\
\hline HW-4 & 828104 & 1040460 & 2043 & 7.34 & 708 & 474 & 228.5 & 325.5 & $\mathrm{Ca}-\mathrm{HCO}_{3}$ & Granite \\
\hline HW-5 & 828272 & 1041936 & 2031 & 7.68 & 528 & 336 & 193.8 & 238.7 & Ca-Na-HCO ${ }_{3}$ & Granite \\
\hline HW-7 & 170767 & 1041348 & 2018 & 7.54 & 793 & 500 & 255 & 345 & $\mathrm{Ca}-\mathrm{Na}-\mathrm{HCO}_{3}-\mathrm{Cl}$ & Lacustrine \\
\hline HW-8 & 172611 & 1040355 & 2014 & 7.65 & 966 & 648 & 354.96 & 427.5 & $\mathrm{Ca}-\mathrm{Mg}-\mathrm{Na}-\mathrm{HCO}_{3}-\mathrm{SO}_{4}$ & Lacustrine \\
\hline HW-9 & 171799 & 1040751 & 2011 & 7.38 & 2920 & 1890 & 291.7 & 868 & $\mathrm{Na}-\mathrm{Ca}-\mathrm{Mg}-\mathrm{Cl}-\mathrm{SO}_{4}$ & Lacustrine \\
\hline HW-10 & 173319 & 1042855 & 2020 & 7.68 & 484 & 318 & 148.9 & 151.9 & $\mathrm{Na}-\mathrm{Ca}-\mathrm{Mg}-\mathrm{HCO}_{3}-\mathrm{SO}_{4}$ & Lacustrine \\
\hline SP-1 & 178675 & 1044507 & 2203 & 7.09 & 628 & 404 & 310.1 & 332.01 & $\mathrm{Ca}-\mathrm{Mg}-\mathrm{HCO}_{3}$ & Sandstone \\
\hline SP-2 & 178049 & 1044093 & 2181 & 7.15 & 669 & 418 & 326.4 & 349.4 & $\mathrm{Ca}-\mathrm{Mg}-\mathrm{HCO}_{3}$ & Sandstone \\
\hline SP-4 & 177517 & 1043059 & 2113 & 7.06 & 780 & 494 & 346.8 & 386.3 & $\mathrm{Ca}-\mathrm{Mg}-\mathrm{HCO}_{3}$ & Granite \\
\hline Sp-6 & 178840 & 1042810 & 2126 & 7 & 736 & 448 & 354.9 & 438.3 & $\mathrm{Ca}-\mathrm{Mg}-\mathrm{HCO}_{3}$ & Granite \\
\hline BH-0 & 174135 & 1041428 & 2028 & 7.66 & 804 & 494 & 352.9 & 412.3 & Ca-Mg-HCO 3 & Alluvial \\
\hline BH-1 & 173975 & 1041732 & 2028 & 7.36 & 702 & 444 & 269.3 & 256.1 & $\mathrm{Ca}-\mathrm{Na}-\mathrm{HCO}_{3}$ & Alluvial \\
\hline BH-7 & 173925 & 1042432 & 2028 & 7.35 & 1033 & 632 & 446.8 & 509.9 & $\mathrm{Ca}-\mathrm{Mg}-\mathrm{HCO}_{3}$ & Alluvial \\
\hline
\end{tabular}

\begin{tabular}{|c|c|c|c|c|c|c|c|c|c|c|c|c|c|c|c|}
\hline & HW-1 & HW-3 & HW-4 & HW-5 & HW-7 & $H W-8$ & HW-9 & $H W-10$ & SP-1 & SP-2 & SP-4 & $S P-6$ & BH-0 & BH-1 & BH-7 \\
\hline $\mathrm{Na}^{+}$ & 11.7 & 19 & 32 & 28 & 51 & 70 & 290 & 52 & 6.3 & 7.3 & 10.7 & 6.5 & 31 & 61 & 51 \\
\hline$\overline{\mathrm{K}^{+}}$ & 1.4 & 1 & 4.6 & 1.8 & 2 & 1.3 & 2.3 & 2.6 & 0.6 & 0.8 & 8 & 1.3 & 1.4 & 2.4 & 1.7 \\
\hline $\mathrm{Ca}^{+2}$ & 91.4 & 121.8 & 106.1 & 78.3 & 108.8 & 96.6 & 182.7 & 35.7 & 93.1 & 91.35 & 101.8 & 122.7 & 126.2 & 76.6 & 152.3 \\
\hline $\mathrm{Mg}^{+2}$ & 35.3 & 15.2 & 13.7 & 9.8 & 16.7 & 42.14 & 93.1 & 14.2 & 22.54 & 27.44 & 29.9 & 29.9 & 22.1 & 14.7 & 29.4 \\
\hline $\mathrm{Fe}_{\mathrm{Tot}}$ & 0.03 & Trace & Trace & Trace & Trace & Trace & Trace & 0.02 & Trace & Trace & Trace & Trace & Trace & Trace & Trace \\
\hline $\mathrm{Mn}^{+2}$ & Trace & Trace & Trace & Trace & 0.05 & 0.02 & 0.05 & Trace & Trace & Trace & Trace & Trace & Trace & 0.02 & Trace \\
\hline $\mathrm{F}^{-}$ & 0.15 & 0.5 & 0.45 & Trace & 0.5 & 0.8 & 0.5 & 1.1 & Trace & 0.5 & 0.15 & Trace & Trace & 0.96 & 0.45 \\
\hline $\mathrm{Cl}^{-}$ & 14.3 & 19.95 & 46.6 & 28.5 & 63.7 & 42.8 & 461.7 & 35.2 & 9.5 & 8.6 & 19 & 12.4 & 31.4 & 37.1 & 57 \\
\hline $\mathrm{NO}_{3}^{-}$ & 12.5 & 7 & 14.25 & 21.5 & 5 & 5 & 17.5 & 8.5 & 19.5 & 19.5 & 14.3 & 14.25 & 8 & 10 & 8 \\
\hline $\mathrm{CO}_{3}^{-2}$ & Trace & Trace & Trace & Trace & Trace & Trace & Trace & Trace & Trace & Trace & Trace & Trace & Trace & Trace & Trace \\
\hline $\mathrm{HCO}_{3}^{-}$ & 395.7 & 418.1 & 278.7 & 236.4 & 311.1 & 433 & 355.9 & 181.7 & 378.3 & 398.2 & 423.1 & 433 & 430.6 & 328.5 & 545 \\
\hline $\mathrm{SO}_{4}^{-2}$ & 11.28 & 17.33 & 49.5 & 19.3 & 66 & 151.3 & 467.5 & 71.5 & 11.5 & 11 & 26.95 & 17.33 & 24.75 & 71.5 & 24.7 \\
\hline $\mathrm{PO}_{4}^{-3}$ & 0.08 & 0.103 & 0.123 & 0.062 & 0.041 & 0.08 & 0.041 & 0.062 & 0.041 & 0.062 & 0.062 & 0.041 & 0.246 & 0.08 & 0.062 \\
\hline $\mathrm{NH}_{4}^{+}$ & 0.275 & 0.15 & 0.15 & 0.25 & 0.22 & 0.26 & 0.65 & 0.39 & 0.13 & 0.188 & 0.188 & 0.4 & 0.15 & 0.13 & 0.65 \\
\hline
\end{tabular}

